\title{
ОЦЕНКА ВЛИЯНИЯ ГИБРИДНЫХ \\ ОЛОВООРГАНИЧЕСКИХ СОЕДИНЕНИЙ НА ИНТЕНСИВНОСТЬ МЕТАСТАЗИРОВАНИЯ
}

\author{
М.А. Додохова', И.М. Котиева², А.В. Сафроненко, \\ М.С. Алхусейн-Кулягинова ${ }^{4}$, Д.Б. Шпаковский5, Е.Р. Милаева ${ }^{5}$ \\ ${ }^{1}$ Кафедра биомедицины и психофизиологии, \\ ${ }^{2}$ Кафедра патологической физиологии, \\ ${ }^{3}$ Кафедра фармакологии и клинической фармакологии, \\ ${ }^{4}$ Кафедра химии, Ростовский медицинский государственный университет, \\ 344022, Россия, Ростов-на-Дону, Нахичеванский пер., д. 29. \\ ${ }^{5}$ Кафедра медицинской химии и тонкого органического синтеза, Московский \\ государственный университет им. М.В. Ломоносова, Химический факультет, \\ 119991, Россия, Москва, Ленинские горы, д. 1, стр. 3.
}

DOI: 10.19163/MedChemRussia2021-2021-125

E-mail:dodohova@mail.ru

Оловоорганические соединения, содержащие протекторный фрагмент 2,6-диmрет-бутилфенола, являются перспективными кандидатами в противоопухолевые агенты $[1,2]$. Влияние соединений ((3,5-ди-трет-бутил-4-гидроксифенилтиолат) трифенилолова (Ме-5), (бис(3,5-ди-трет-бутил-4-гидроксифенилтиолат) диметилолова (Ме-3) на интенсивность процесса метастазирования в легкие было изучено на классических моделях перевиваемых опухолей мышей - меланоме В16 и эпидермоидной карциноме Lewis (LLC). Через 48 часов после подкожной перевивки опухолевого материала производили пятикратное внутрибрюшинное введение Me3 и Me5 в диапазоне доз от 30 мг/кг/сут до 75 мг/кг/сут. На 18 сутки (Mе3) и 21 сутки (Ме5) была произведена эвтаназия животных с определением индекса ингибирования метастазирования. Результаты исследования представлены на диаграмме.

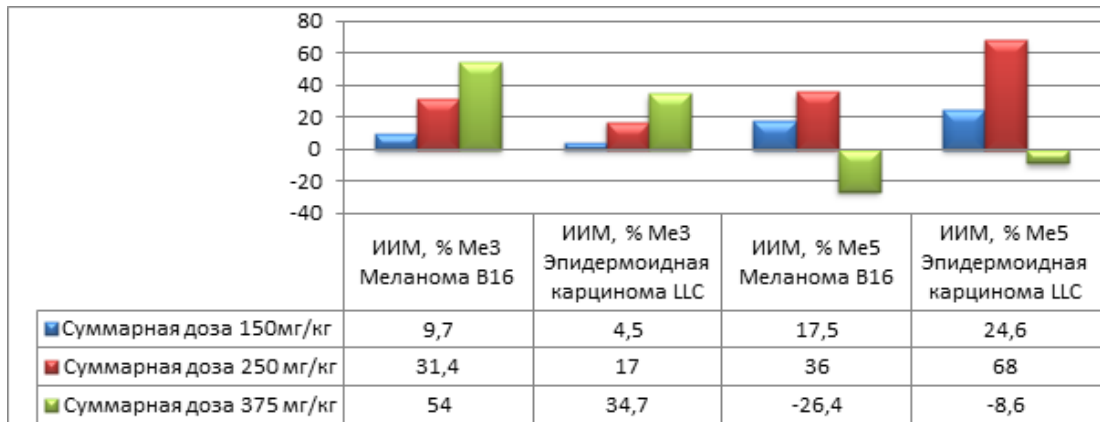

Работа выполнена при финансовой поддержке РНФ (19-13-00084).

\section{Литература}

[1] T.A. Antonenko, D.B. Shpakovsky, et al., Appl. Organomet. Chem., 2018, 32, e4381.

[2] E.R. Milaeva, D.B. Shpakovsky, et al, Pure and Applied Chemistry, 2020, 92, 1201-1216.

$$
-125-
$$

